Vol. XXIII No $1 \quad 2017$

\title{
SECURITY, DEFENCE AND ARMED FORCES - PUBLIC VIEW
}

\author{
Frank LIBOR \\ University of Defence, Brno, The Czech Republic \\ libor.frank@unob.cz
}

\begin{abstract}
The paper deals with the interpretation of public opinion polls in the Czech Republic related to security, defence and armed forces. In recent years, we can observe concern about the security situation development in the relatively close vicinity of the Czech Republic. In particular, information regarding the activities of the so-called Islamic State, the conflict in Ukraine and media presentation of recent terrorist attacks, as well as the dominant securitization of migration, have a major impact on the public opinion and the level of support for specific steps of the government in the field of security and defence policy. In the surveys, we can trace not only the growing public concern, but also the increasing support for higher defence spending and possible reintroduction of some form of compulsory military service. Special attention is paid to the public perception of the armed forces and the interpretation of the latest public opinion polls at the turn of 2016/2017. The growing support for the military and the increasing willingness of the public to engage in the Active Reserve System are positive factors that can be used to meet the recruiting goals of the Czech Armed Forces.
\end{abstract}

\section{Keywords: public polls, threats, public attitudes, security and defence issues}

\section{Introduction}

It must be said that in the last few years in the Czech Republic as well as in other countries in Central Europe, it is possible to observe an increasing public concern and also an increase in fear of specific threats or phenomena that are interpreted and securitized in this respect. This development is very clear, especially if we compare e.g. the present results of public opinion polls with the data that characterized the popular feelings and concerns over the past decades.

\section{What we were afraid of previously}

For example, still in 2001, before the terrorist attacks of September 11, $88 \%$ of respondents - citizens of the Czech Republic believed that no military threats existed. [1] The events of September 2001 in the United States, highly covered in media, statements of the leading representatives of the country, especially former Prime Minister (and current president of the country) Miloš Zeman, as well as specific and visible security measures (let us recall the IFVs in the centre of Prague around the Free Europe radio buildings), all this affected the public and the sense of security has never returned to the level of the beginning of the last decade. Still, the concerns of citizens were related, in particular, to the issues of their social and economic status.

Unemployment, sickness, decrease in living standards, crime - these were the sources of the concerns that the public primarily perceived. Wars, arms race, terrorism and other phenomena associated with national or international security, were in fact less significant to the public. [2] 


\section{What we are afraid of now}

Today, the situation is more complicated. The focus of public interest is occupied by phenomena that were previously considered as not relevant to our geographic area or were entirely absent from the public discourse. In particular, the concerns about migration, terrorism and war are new and they are viewed much more sensitively by the public. [3]

Despite the economic growth and rising living standards, paradoxically, there is growing feeling of discomfort, scepticism and pessimism in the issues of the future development of security of our country and the whole of Europe. There are significant concerns about conflicts and war that could involve our region. More than $80 \%$ of respondents in the Czech Republic think that war is a threat for our country - even for $37 \%$ it is a big threat, which is roughly three times higher compared to the situation ten years ago! [4]

Overall, the security situation in Europe is seen quite negative and, according to the public, further development does not promise a better turn. Today, only about $4 \%$ of respondents declare that in the past five years the security situation in Europe has improved, for $14 \%$ it has not changed, but for more than $80 \%$ it has deteriorated (for $43 \%$ of them significantly). [5]

Media presentation and political interpretation of the activities of the so-called Islamic State, the terrorist attacks in Europe, annexation of Crimea and the rising tension in relations between Russia and the West as well as the migration crisis and its association with terrorism, all this gives the public a sense of fear and uncertainty, but it also raises the demand for instant, strong, simple measures that would bring the feeling of security back. Especially the mentioned events and their presentation influenced, in a significant way, the public interest in the security issues in general and also contributed to the creation of a dominant, rigid and negatively defined public attitudes.

\section{Migration - example of securitization of a non-existent threat}

This development can be clearly demonstrated with the attitude toward the migration crisis and acceptance of refugees that most of the public (3/4) consider not as people in need, rather as a security threat to the Czech Republic, Europe and the global peace. [6]

It is a paradox, indeed, as at the height of the migration crisis in 2015, when almost two million migrants came to Europe, including several hundred thousand to neighbouring Germany, the Czech Republic was affected by this wave only marginally. In 2015, around 8,000 illegal migrants were detained in its territory; in the last year, it was about half of this number. A little above 1,500 migrants applied for asylum in 2015; less than 1,400 last year. [7]

However, the overwhelming majority of applicants for asylum contributing to these figures were from Ukraine, Cuba, Vietnam, China and the post-soviet countries. Applicants for asylum from Syria, Iraq or Afghanistan amounted to several tens, still, the subject of migration and refugees has become the subject of great media, political and public interest on the edge of hysteria. [8] All of this in a situation where the ordinary citizen essentially does not have a chance to physically meet a refugee, let alone learn anything about their story. It is tragic that this refusal applies not only to the economic migrants, but also to people fleeing war and looking for a safe haven in our secular country that, paradoxically, at least in words, if not deeds, asserts the untouchability of Christian values. However, even for war refugees there is no place in Czech Republic, as almost two thirds of the Czech citizens do not agree even with the granting of temporary asylum to people fleeing war. [9] Why is the Czech society so unfavourable, frightened, xenophobic? What kind of information raised such public concern over the subject of migration? Why is the migration that we may actually need for economic and in particular demographic 
reasons, interpreted as a threat rather than as an opportunity?

As our own empirical experience with migration is essentially excluded, it can be assumed that migration is securitized, i.e. interpreted as a security threat, by media, certain political forces, president or other persons who have sufficient authority and ability to influence public opinion.

In this context, we can demonstrate the fundamental, dominant and negative impact of the media, including the public service media, which should facilitate information objectively, impartially and professionally. However, based on a number of studies of media coverage of the migration crisis, we can clearly identify their failure and contribution in the securitization of migration. For example, the conclusions of the research project "Analysis of Media Coverage of the Refugee Crisis", [10] aimed at main news programs of two most popular TV stations - public service Czech Television and commercial TV Nova, are clear: "Covering of the refugee crisis in the main news programs of both TV stations was not balanced and it unilaterally emphasized the security and administrative risks associated with immigration. Thus presented news could make the viewers feel threatened and increase the demand for short-term solutions to the problem with the use of force."

It can be presumed that the conclusions of the analysis can be applied to other media, tabloids notwithstanding.

Emphasizing the security and administrative aspects of migration, introducing fear of economic costs, increased criminality, introduction of diseases, etc., strengthen the public rejection of all migrants. In addition, linking migration to islamization [11] and terrorism leads to the creation of a simplistic and false negative stereotype: refugee $=$ Muslim $=$ terrorist.

Based on the empirical data from public opinion polls, it seems that this interpretation of migration is accepted by a considerable part of the Czech society. It feels threatened by immigration and requires strong, fast, simple and forceful or restrictive measures by the state or all those who match these concerns meet with their political offering.

\section{Changes in attitude to defence and armed forces}

The political scene also responds to the growing public concerns, which are reflected in the content of the recently updated strategic documents of the Czech Republic However, while the public sees the biggest danger in illegal and mass migration, the official documents are dominated by the issue of international terrorism and the concerns with the activities of the Russian Federation. All these threats and their frequent media and political interpretation contribute to the overall sense of danger and modify the long-term public attitudes toward defence issues and the armed forces.

While the past decades showed relatively little public interest in the army and the low level of awareness of the defence matters, in recent years an empirically evidenced change has occurred. The defence department is no longer perceived as a reserve for the state budget and defence spending has become a legitimate and desirable expense of the state in the eyes of the public. The turnover in the ratio of views on the importance of defence spending in public opinion polls can be observed approximately since 2014. Since 1993 (with the exception of 1999, when the Czech Republic entered NATO) most of the public always considered this expenditure too burdensome for the state budget (51$58 \%$ ); since 2014 this view represents minority of respondents $(39-41 \%)$. At the end of 2016, as many as $63 \%$ of respondents directly voiced support for an increase in spending on defence. [12]

According to the research „Army and Security 2016" by the Ministry of Defence, there is also an apparent growing confidence in the army and support for the introduction of some form of military training or training of the population. The army enjoys a high level of public confidence (more than $70 \%$ of 
respondents express trust in the army, more than e.g. police; twenty years ago, the confidence in the army was under $30 \%$ ). The prestige of the military officer has increased dramatically and is comparable with the public recognition of a judge or university professor. [13]

The army is seen as necessary for the defence of the state, but the public is aware of its lack of capacities and the limits in securing defence and security of the state, which are the result of long-term underinvestment. Low numbers of the fully professional army along with the growing concern about the development of the security situation strengthen the public support for the reintroduction of military service or other forms of military preparation of the population. Still in 2012 the decision to abolish conscription was viewed as correct $65 \%$; at the end of 2016 it was already only half of the respondents $(42 \%$ agree with renewing the basic military service!). [14]

In comparison to previous years and decades, there is also an increase in the willingness of the public to participate in the defence of the state. Nearly $9 \%$ of respondents would be more willing to become a professional soldier, serve in the Military Police or the Castle Guard and work in a military profession. Even more, 19\% of respondents, are willing to become a member of a socalled Active Reserve, in addition to their civilian occupation, participate in regular training and receive a monthly allowance from the state. One third of respondents (33\%) are even willing to participate in single short-term voluntary exercises along with their civilian occupation.

The evaluation of the military as an employer is also positive, up to $66 \%$ of responding citizens consider the army as a good employer and only $8 \%$ answered in negative. [15]

The data and the trends are likely to facilitate the implementation of the updated militarypolitical ambitions of the Czech Republic. The updated document The Defence Strategy of the Czech Republic [16], which the government adopted in March 2017, expects a significant increase in defence expenditure (up to 2\% of GDP by 2024; in 2016 spending amounted to $1.03 \%$ of GDP), modernization of the armed forces and in particular significant increase in the number of professional soldiers up to nearly 30,000 $(23,184$ professionals served in 2016). [17]

\section{Conclusion}

The growing public concern over threats or phenomena that are presented so by the media, political elites, president or persons considered experts by the public is evident. Russian assertive to aggressive foreign policy activities, terrorist attacks, mass migration - these are all factors which are sensitively perceived and empirical researches show significant and in recent decades unprecedented shifts in the public attitudes.

It can be assumed that there is a link between these concerns and the pessimism of the public and the growing support for the actions of the state to increase its defence capabilities. The extraordinary support for an increase in defence spending, growing interest in the military service and in Active Reserve represent a significant opportunity for the armed forces of the Czech Republic. Despite some improvements in their situation in recent years, they still have to deal with the aftermath of the long-term shortage in funding and political and public support.

However, the current favourable economic situation, the existing political will and the growing clear public support offer hope for significant improvement in the conditions for the modernization and strengthening of the armed forces and achieving their best military capabilities.

\section{Acknowledgements}

The work presented in this paper has been supported by the Ministry of Defence of the Czech Republic (Research Project “STRATAL” No. 907930101023). 


\section{References}

[1] VINOPAL, Jiří. Pět let v NATO: Vojenské, politické a společenské aspekty členství ČR v NATO, IIPS, Ostrava, Jagello 2000, 2004, p. 85.

[2] REZKOVÁ, Miluše. Reflexe ekonomické transformace a kompetence vlády. In TUČEK, Milan. Odraz společenských změn ve veřejném míněni 1990-1998. Praha : Sociologický ústav Akademie věd České republiky, 1999. ISBN 80-85950-63-4. s. 48.

[3] http://cvvm.soc.cas.cz/media/com form2content/documents/c1/a7659/f3/ov170209.pdf

[4] http://cvvm.soc.cas.cz/media/com form2content/documents/c1/a7648/f3/ob170117.pdf

[5] Ibid.

[6] http://cvvm.soc.cas.cz/media/com form2content/documents/c1/a7680/f3/pm170327.pdf

[7] http://www.emncz.eu/statistiky/

[8] http://www.mvcr.cz/soubor/cs-stat-2016-pdf.aspx

[9] http://cvvm.soc.cas.cz/media/com form2content/documents/c1/a7680/f3/pm170327.pdf

[10] TKACZYK, Michal, Pavel POSPĚCH a Jakub MACEK. Analýza mediálního pokrytí uprchlické krize (výzkumná zpráva). Brno: Masarykova univerzita, 2015. doi:10.13140/RG.2.1.4957.5764.

[11] STOJAR, Richard. Obrana a strategie, Vol. 16, No. 1, pp. 61-78, 2016.

[12] Armáda a verejnost 2015, Czech MoD, unpublished.

[13] Armáda a bezpečnost 2016, Czech MoD, unpublished.

[14] Ibid.

[15] Ibid.

[16] http://www.mocr.army.cz/images/id 40001 50000/46088/OS.pdf

[17] http://www.mocr.army.cz/assets/dokumenty-a-legislativa/cisla/att00022-doc.xls 